\title{
IPTEKS PENGHITUNGAN PAJAK PENGHASILAN PASAL 21 BAGI PENGUSAHA KECIL BERDASARKAN PERATURAN MENTERI KEUANGAN REPUBLIK INDONESIA NOMOR 162/PMK.011/2012
}

\author{
Novi Swandari Budiarso ${ }^{1}$ \\ ${ }^{1}$ Jurusan Akuntansi, Fakultas Ekonomi dan Bisnis, Universitas Sam Ratulangi, Jl. Kampus Bahu, Manado, \\ 95115, Indonesia \\ E-mail : novi.sbudiarso@unsrat.ac.id
}

\begin{abstract}
Tax used by government for financing all operational to develop the state. Income tax article 21 is the one of tax usually for individual which is most important income for state. The most problem for income tax article 21 is miscalculation for most of individual as taxpayer. The application to calculate the income tax article 21 for this study is regulation of Finance Ministry of Republic of Indonesia number 162/PMK.011/2012.
\end{abstract}

Keywords : Income tax article 21, small business, self assessment system

\section{PENDAHULUAN}

Pajak merupakan salah satu alat bagi negara untuk memperoleh dana (Susan, 2013) guna melaksanakan pembangunan dalam rangka mewujudkan kesejahteraan masyarakat seperti yang tercantum dalam Undang-Undang Dasar Negara. Adapun salah satu objek dari pemungutan pajak tersebut adalah masyarakat Dewanata, dkk (2013), termasuk di dalamnya adalah masyarakat yang menyelenggarakan usaha kecil. Akan tetapi, untuk mewujudkan keseimbangan dalam pemungutan pajak, maka Negara dalam hal ini Pemerintah, menerapkan pajak berdasarkan asas daya pikul, sehingga pemungutan pajak tidak memberatkan masyarakat yang dikenakan dan dipungut pajaknya. Asas daya pikul dari pajak adalah bahwa beban pajak untuk semua orang harus sama beratnya, dimana pajak yang harus dibayar adalah sesuai dengan daya pikul masing-masing orang (Mardiasmo, 2011).

Akan tetapi, pada prakteknya, pemungutan pajak itu sendiri masih memiliki banyak halangan dan tantangan yang berasal dari masyarakat itu sendiri, misalnya ; kesadaran akan membayar pajak masih kurang dalam masyarakat, krisis kepercayaan publik pada pemerintah dan juga pemahaman akan perpajakan itu sendiri masih sangat kurang baik dari segi perhitungan, pembayaran sampai pada pelaporannya (dalam hal ini Menghitung Pajak Sendiri - Self Assessment System), sehingga tak jarang menimbulkan hambatan dalam pembayaran pajak itu sendiri.

Pajak Penghasilan Pasal 21 merupakan salah satu jenis pajak yang dipungut oleh pemerintah kepada masyarakat yang memiliki penghasilan dari hasil pekerjaannya (Suprajadi, 1999). Permasalahan dalam praktek lapangan adalah, masyarakat sering tidak mengerti tata cara penghitungan pajak, karena kurangnya informasi praktis yang membantu masyarakat untuk menentukan besarnya jumlah pajak yang harus dipungut. Hal ini juga ditunjang dengan kurangnya kesadaran masyarakat untuk melakukan konsultasi dengan pihak fiskus guna memperoleh informasi atas perkembangan yang terjadi dalam bidang perpajakan atau disebabkan oleh karena kurangnya sosialisasi dari fiskus (Ernawati \& Wijaya, 2011).

Berdasarkan latar belakang ini, maka penulis merasa sangat penting untuk melakukan pembahasan secara ilmiah terkait dengan masalah penghitungan guna penentuan besarnya pajak yang seharusnya dipotong, disetorkan dan dilaporkan oleh masyarakat sendiri, sebagai wujud semangat Tri Dharma Perguruan Tinggi, untuk memberikan kontribusi kepada masyarakat melalui karya pengabdian pada masyarakat. 


\section{TINJAUAN PUSTAKA}

\subsection{Definisi Pajak}

Menurut Mardiasmo (2011) dan Setiyaji \& Amir (2005), pajak memiliki definisi dengan unsur-unsur sebagai berikut :

1. Iuran dari rakyat kepada negara.

Yang berhak memungut pajak adalah negara. Iuran tersebut berupa uang (bukan barang).

2. Berdasarkan undang-undang.

Pajak dipungut berdasarkan atau dengan kekuatan undang-undang serta aturan pelaksanaannya.

3. Tanpa jasa timbal atau kontraprestasi dari negara yang secara langsung dapat ditunjuk. Dalam pembayaran pajak tidak dapat ditunjukkan adanya kontraprestasi individual oleh pemerintah.

4. Digunakan untuk membiayai rumah tangga negara, yakni pengeluaran-pengeluaran yang bermanfaat bagi masyarakat luas.

\subsection{Fungsi Pajak}

Mardiasmo (2011) membagi fungsi pajak dalam 2 (dua) kelompok, yaitu :

1. Fungsi Budgetair. Pajak sebagai sumber dana bagi pemerintah untuk membiayai pengeluaran-pengeluarannya.

2. Fungsi Mengatur (regulerend). Pajak sebagai alat untuk mengatur atau melaksanakan kebijaksanaan pemerintah dalam bidang sosial dan ekonomi.

\subsection{Syarat Pemungutan Pajak}

Beberapa syarat pemungutan pajak menurut Mardiasmo (2011) adalah :

1. Syarat Keadilan. Sesuai dengan tujuan hukum, yakni mencapai keadilan, undang-undang dan pelaksanaan pemungutan harus adil, dalam arti mengenakan pajak secara umum dan merata, serta disesuaikan dengan kemampuan masing-masing.

2. Syarat Yuridis. Sesuai dengan UUD 1945 pasal 23 ayat 2, bahwa terdapat jaminan hukum untuk menyatakan keadilan, baik bagi negara maupun warganya.

3. Syarat Ekonomis. Pemungutan tidak boleh mengganggu kelancaran kegiatan produksi maupun perdagangan, sehingga tidak menimbulkan kelesuan perekonomian masyarakat.

4. Syarat Finansiil. Sesuai fungsi budgetair, biaya pemungutan pajak harus dapat ditekan sehingga lebih rendah dari hasil pemungutannya.

5. Sistem pemungutan pajak harus sederhana. Sistem pemungutan yang sederhana akan memudahkan dan mendorong masyarakat dalam memenuhi kewajiban perpajakannya. Syarat ini telah dipenuhi oleh undang-undang perpajakan yang baru.

\subsection{Pengelompokkan Pajak}

Mardiasmo (2011), mengelompokkan pajak sebagai berikut :

1. Menurut golongannya.

a. Pajak langsung, yaitu pajak yang harus dipikul sendiri oleh wajib pajak dan tidak dapat dibebankan atau dilimpahkan kepada orang lain.

b. Pajak tidak langsung, yaitu pajak yang pada akhirnya dapat dibebankan atau dilimpahkan kepada orang lain.

2. Menurut sifatnya.

a. Pajak subjektif, yaitu pajak yang berpangkal atau berdasarkan pada subjeknya, dalam arti memperhatikan keadaan diri wajib pajak.

b. Pajak objektif, yaitu pajak yang berpangkal pada objeknya, tanpa memperhatikan keadaan diri wajib pajak.

3. Menurut lembaga pemungutnya.

a. Pajak pusat, yaitu pajak yang dipungut oleh pemerintah pusat dan digunakan untuk membiayai rumah tangga negara. 
b. Pajak daerah, yaitu pajak yang dipungut oleh Pemerintah Daerah dan digunakan untuk membiayai rumah tangga daerah.

\subsection{Tarif Pajak}

Mardiasmo (2011), membagi tarif pajak sebagai berikut :

1. Tarif sebanding.

Tarif berupa persentase yang tetap, terhadap berapapun jumlah yang dikenai pajak sehingga besarnya pajak yang terutang proporsional terhadap besarnya nilai yang dikenai pajak.

2. Tarif tetap.

Tarif berupa jumlah yang tetap (sama) terhadap berapapun jumlah yang dikenai pajak sehingga besarnya pajak yang terutang tetap.

3. Tarif progresif.

Persentase tarif yang digunakan semakin besar bila jumlah yang dikenai pajak semakin besar.

Berdasarkan Undang-Undang Nomor 36 tahun 2008, maka tarif progresif diterapkan untuk menghitung pajak penghasilan, dengan uraian sebagai berikut :

Lapisan Penghasilan Kena Pajak

Rp. 0 - Rp. 50.000 .000

Tarif Pajak

Diatas Rp. 50.000 .000 - Rp. $250.000 .000 \quad 15 \%$

Diatas Rp. 250.000 .000 - Rp. $500.000 .000 \quad 25 \%$

Diatas Rp. 500.000.000 30\%

Lebih lanjut diatur dalam Undang-Undang Nomor 36 tahun 2008, pasal 17, ayat 2, dikatakan bahwa, tarif tertinggi dapat diturunkan menjadi paling rendah $25 \%$ (dua puluh lima persen) yang diatur dengan Peraturan Pemerintah.

\subsection{Penghasilan Tidak Kena Pajak (PTKP) dan Biaya Jabatan dalam PPh 21}

Peraturan Menteri Keuangan Republik Indonesia Nomor : 162/PMK.011/2012 tentang Penyesuaian Besarnya Penghasilan Tidak Kena Pajak, pasal 1 menyebutkan bahwa, besarnya penghasilan tidak kena pajak disesuaikan menjadi sebagai berikut:

a. Rp24.300.000,00 (dua puluh empat juta tiga ratus ribu rupiah) untuk diri Wajib Pajak orang pribadi;

b. Rp2.025.000,00 (dua juta dua puluh lima ribu rupiah) tambahan untuk Wajib Pajak yang kawin;

c. Rp24.300.000,00 (dua puluh empat juta tiga ratus ribu rupiah) tambahan untuk seorang isteri yang penghasilannya digabung dengan penghasilan suami sebagaimana dimaksud dalam Pasal 8 ayat (1) Undang-Undang Nomor 7 Tahun 1983 tentang Pajak Penghasilan sebagaimana telah beberapa kali diubah terakhir dengan Undang-Undang Nomor 36 Tahun 2008;

d. Rp2.025.000,00 (dua juta dua puluh lima ribu rupiah) tambahan untuk setiap anggota keluarga sedarah dan keluarga semenda dalam garis keturunan lurus serta anak angkat, yang menjadi tanggungan sepenuhnya, paling banyak 3 (tiga) orang untuk setiap keluarga.

Sedangkan dalam pasal 3, dalam peraturan yang sama menegaskan bahwa penyesuaian besarnya penghasilan tidak kena pajak sebagaimana dimaksud dalam pasal 1 mulai berlaku pada tanggal 1 Januari 2013. Ketentuan dalam peraturan ini kembali ditegaskan oleh Peraturan Direktur Jenderal Pajak Nomor : PER - 31/PJ/2012, pasal 11, sebagai berikut :

1. Besarnya PTKP per tahun adalah sebagai berikut : 

a. Rp24.300.000,00 (dua puluh empat juta tiga ratus ribu rupiah) untuk diri Wajib Pajak orang pribadi;
b. Rp2.025.000,00 (dua juta dua puluh lima ribu rupiah) tambahan untuk Wajib Pajak yang kawin;
c. Rp2.025.000,00 (dua juta dua puluh lima ribu rupiah) tambahan untuk setiap anggota keluarga sedarah dan keluarga semenda dalam garis keturunan lurus serta anak angkat, yang menjadi tanggungan sepenuhnya, paling banyak 3 (tiga) orang untuk setiap keluarga.

2. PTKP per bulan sebagaimana dimaksud dalam Pasal 10 ayat (2) huruf c adalah PTKP per tahun sebagaimana dimaksud pada ayat (1) dibagi 12 (dua belas), sebesar :
a. Rp2.025.000,00 (dua juta dua puluh lima ribu rupiah) untuk diri Wajib Pajak orang pribadi;

b. Rp168.750,00 (seratus enam puluh delapan ribu tujuh ratus lima puluh rupiah) tambahan untuk Wajib Pajak yang kawin;

c. Rp168.750,00 (seratus enam puluh delapan ribu tujuh ratus lima puluh rupiah) tambahan untuk setiap anggota keluarga sedarah dan keluarga semenda dalam garis keturunan lurus serta anak angkat, yang menjadi tanggungan sepenuhnya, paling banyak 3 (tiga) orang untuk setiap keluarga.

3. Besarnya PTKP bagi karyawati berlaku ketentuan sebagai berikut :

a. bagi karyawati kawin, sebesar PTKP untuk dirinya sendiri;

b. bagi karyawati tidak kawin, sebesar PTKP untuk dirinya sendiri ditambah PTKP untuk keluarga yang menjadi tanggungan sepenuhnya.

Masalah pembebanan pajak penghasilan pada karyawati oleh Anggarsari (2010), dalam hasil penelitiannya menemukan bahwa pemberian hak bagi wajib pajak wanita kawin untuk memilih menjalankan hak dan kewajiban perpajakannya sendiri merupakan upaya untuk memberikan hak dan kewajiban yang sama bagi wajib pajak tanpa memperhatikan jenis kelaminnya. Lebih lanjut dalam Pasal 10 ayat 3 huruf a, ditegaskan bahwa biaya jabatan adalah sebesar 5\% (lima persen) dari penghasilan bruto, atau setinggi-tingginya Rp.500.000,00 (lima ratus ribu rupiah) sebulan atau Rp.6.000.000,00 (enam juta rupiah) setahun.

\section{METODE DAN TEKNIK PENERAPAN IPTEKS}

\subsection{Metode Penerapan Ipteks.}

Penerapan ipteks ditempuh dengan cara menguraikan dan melakukan pembahasan secara ilmiah dengan pendekatan metode studi kasus yang langsung diaplikasikan pada teknis perhitungan dan analisis Pajak Penghasilan Pasal 21.

\subsection{Teknik Penerapan Ipteks.}

Teknik yang digunakan dalam penerapan ipteks atas penghitungan Pajak Penghasilan pasal 21 adalah sebagai berikut :

1. Penghasilan Bruto.

Dalam tahap ini, akan dijelaskan apa yang dimaksud dengan penghasilan bruto dalam segi perpajakan.

2. Penghasilan Tidak Kena Pajak (PTKP).

Dalam tahap ini, akan dijelaskan dan diuraikan apa yang dimaksud dengan Penghasilan Tidak Kena Pajak (PTKP), termasuk teknis penghitungannya.

3. Biaya Jabatan.

Dalam tahap ini, akan diuraikan tentang penentuan biaya jabatan dan penyesuaian besarnya jumlah biaya jabatan yang dapat dikurangkan dari penghasilan bruto menurut peraturan dan perundangan yang berlaku.

4. Penghasilan Kena Pajak (PKP). 
Dalam tahap ini akan diuraikan tentang teknis penentuan besarnya Penghasilan Kena Pajak (PKP) yang merupakan dasar penentuan besarnya pajak penghasilan dengan menggunakan tarif progresif.

5. Penerapan Tarif Progresif.

Dalam tahap ini, akan diuraikan tentang penerapan tarif progresif sesuai dengan UndangUndang Nomor 36 tahun 2008, untuk penentuan besarnya pajak penghasilan terutang yang harus dipungut.

6. Penentuan Besaran Pajak Penghasilan Pasal 21.

Dalam tahap ini, akan diuraikan besarnya pajak penghasilan yang harus dipungut berdasarkan 2 (dua) kategori wajib pajak, yaitu : menurut wajib pajak yang memiliki Nomor Pokok Wajib Pajak (NPWP) dan wajib pajak yang tidak memiliki Nomor Pokok Wajib Pajak (NPWP) sesuai Peraturan Direktur Jenderal Pajak Nomor : PER 31/PJ/2012, Pasal 20.

\section{HASIL DAN PEMBAHASAN}

\subsection{Gambaran Objek Penerapan Ipteks}

1. Penghasilan Bruto.

Dalam UU No. 36 tahun 2008, penghasilan adalah setiap tambahan kemampuan ekonomis yang diterima atau diperoleh Wajib Pajak, baik yang berasal dari Indonesia maupun dari luar Indonesia, yang dapat dipakai untuk konsumsi atau untuk menambah kekayaan Wajib Pajak yang bersangkutan, dengan nama dan dalam bentuk apa pun. Disebut penghasilan bruto, apabila penghasilan yang dimaksud belum dikurangi biayabiaya yang menjadi konsumsi wajib pajak. Misalnya, Tn. A adalah seorang karyawan yang menerima gaji sebulan sebesar Rp. 100, tunjangan lainnya Rp. 20. Penghasilan bruto sebulan untuk Tn. A adalah Rp. 120, dan apabila disetahunkan akan menjadi Rp. 1.440.

2. Penghasilan Tidak Kena Pajak (PTKP).

Dalm UU No. 36 tahun 2008, PTKP adalah bagian penghasilan bruto yang tidak akan dikenakan pajak. Fasilitas ini diberikan kepada wajib pajak sendiri dan wajib pajak kawin. Untuk wajib pajak kawin, fasilitas ini diberikan untuk istri dan anak (sebanyakbanyaknya 3 orang anak), atau dapat juga berupa tanggungan keluarga. Uraian atas Penghasilan Tidak Kena Pajak (PTKP) menurut Peraturan Menteri Keuangan Nomor 162 tahun 2012 yang dituangkan dalam Peraturan Direktur Jenderal Pajak Nomor 31 tahun 2012 untuk setap jenis wajib pajak yaitu :

\begin{tabular}{lrr}
\hline \multicolumn{1}{c}{ Jenis Wajib Pajak } & PTKP sebulan $($ Rp.) & PTKP setahun (Rp.) \\
\hline Tidak Kawin & 2.025 .000 & 24.300 .000 \\
Kawin - Istri & 168.750 & 2.025 .000 \\
Tanggungan 1 (K/1) & 168.750 & 2.025 .000 \\
Tanggungan 2 (K/2) & 168.750 & 2.025 .000 \\
Tanggungan 3 (K/3) & 168.750 & 2.025 .000 \\
\hline
\end{tabular}

3. Biaya Jabatan.

Dalam Peraturan Direktur Jenderal Pajak Nomor 31 tahun 2012, pasal 10 ayat 3 huruf a, ditegaskan bahwa biaya jabatan adalah sebesar 5\% (lima persen) dari penghasilan bruto, atau setinggi-tingginya Rp.500.000,00 (lima ratus ribu rupiah) sebulan atau Rp.6.000.000,00 (enam juta rupiah) setahun. Misalnya, Tn. A memiliki penghasilan bruto sebesar Rp. 5.000.000 sebulan, biaya jabatan yang dapat dikurangkan dari penghasilan bruto Tn. A adalah Rp. 5.000.000 x 5\% atau sebesar Rp. 250.000. Apabila sebaliknya, jika Tn. A memiliki penghasilan bruto sebesar Rp. 12.000 .000 sebulan, maka biaya jabatan Tn. A dari penghasilan brutonya adalah sebesar Rp. 12.000 .000 x 5\% atau sebesar 
Rp. 600.000, akan tetapi disebabkan karena aturan hanya membatasi hingga Rp. 500.000 sebulan, maka biaya jabatan yang dapat digunakan sebagai pengurang penghasilan bruto adalah Rp. 500.000.

4. Penghasilan Kena Pajak (PKP) dan Penerapan Tarif Progresif.

Penghasilan Kena Pajak (PKP) adalah penghasilan neto yang menjadi dasar untuk diterapkannya tarif progresif guna menentukan besarnya jumlah pajak terutang dalam sebulan atau setahun.

6. Pajak Penghasilan Pasal 21 terutang.

Dalam UU No. 36 tahun 2008 yang dituangkan dalam Peraturan Direktur Jenderal Pajak Nomor 31 tahun 2012 pasal 20, penghitungan atas besarnya pajak penghasilan pasal 21 dapat dibagi berdasarkan 2 (dua) kategori wajib pajak, yaitu menurut wajib pajak yang memiliki Nomor Pokok Wajib Pajak (NPWP) dan wajib pajak yang tidak memiliki Nomor Pokok Wajib Pajak (NPWP). Perhitungan pajak penghasilan antara kedua kategori wajib pajak tersebut adalah :

\subsection{Pembahasan}

Wajib Pajak dengan NPWP $=$ tarif pajak $\mathrm{x}$ lapisan PKP

Wajib Pajak tanpa NPWP $=$ tarif pajak $\times 120 \% \times$ lapisan $\mathrm{PKP}$

Dalam melakukan penghitungan Pajak Penghasilan Pasal 21 menurut UndangUndang No. 36 tahun 2008 akan disesuaikan dengan Peraturan Menteri Keuangan Republik Indonesia Nomor 162 tahun 2012 yang dituangkan dalam Peraturan Direktur Jenderal Pajak Nomor 31 tahun 2012, dan selain itu akan dilakukan perbandingan dengan aturan sebelumnya, sebagai berikut :

1. Wajib Pajak Tidak Kawin.

Alfred adalah seorang karyawan pada sebuah perusahaan swasta, yang menerima gaji per bulan sebesar Rp. 4.500.000, ditambah dengan tunjangan per bulan lainnya sebesar Rp. 600.000. Status perkawinan Alfred pada tanggal 1 Januari 2014 adalah tidak kawin. Dalam hal ini, perhitungan Pajak Penghasilan Pasal $21(\mathrm{PPh} 21)$ per bulan dari Alfred adalah sebagai berikut :

Penghasilan Bruto :

Gaji pokok sebulan

Tunjangan

Total Penghasilan Bruto

4.500 .000

600.000

5.100 .000

Pengurangan :

Biaya Jabatan (5\%)

Penghasilan Neto

$\frac{255.000}{4.845 .000}$

Penghasilan Tidak Kena Pajak :

Wajib Pajak sendiri

Penghasilan Kena Pajak

$\frac{2.025 .000}{\mathbf{2 . 8 2 0 . 0 0 0}}$

Pajak Penghasilan 21 sebulan jika memiliki NPWP :

Rp. 2.820.000 x 5\%

141.000

Pajak Penghasilan 21 sebulan jika tanpa NPWP : Rp. 2.820.000 x 5\% x 120\%

169.200

2. Wajib Pajak Kawin tanpa Tanggungan.

Alfred adalah seorang karyawan pada sebuah perusahaan swasta, yang menerima gaji per bulan sebesar Rp. 4.500.000, ditambah dengan tunjangan per bulan lainnya sebesar Rp. 
600.000. Status perkawinan Alfred pada tanggal 1 Januari 2014 adalah kawin tanpa anak. Dalam hal ini, perhitungan Pajak Penghasilan Pasal $21(\mathrm{PPh} 21)$ per bulan dari Alfred adalah sebagai berikut :

Penghasilan Bruto :

Gaji pokok sebulan

Tunjangan

Total Penghasilan Bruto

Pengurangan :

Biaya Jabatan (5\%)

Penghasilan Neto

$\frac{255.000}{4.845 .000}$

Penghasilan Tidak Kena Pajak :

Wajib Pajak sendiri

Kawin - Istri (K)

168.750

Total Penghasilan Tidak Kena Pajak

Penghasilan Kena Pajak

Pajak Penghasilan 21 sebulan jika memiliki NPWP :

Rp. 2.651.250 x 5\%

132.563

Pajak Penghasilan 21 sebulan jika tanpa NPWP :

Rp. $2.651 .250 \times 5 \% \times 120 \%$

159.075

3. Wajib Pajak Kawin dengan Tanggungan 1 Anak.

Alfred adalah seorang karyawan pada sebuah perusahaan swasta, yang menerima gaji per bulan sebesar Rp. 4.500.000, ditambah dengan tunjangan per bulan lainnya sebesar Rp. 600.000. Status perkawinan Alfred pada tanggal 1 Januari 2014 adalah kawin dengan memiliki 1 orang anak. Dalam hal ini, perhitungan Pajak Penghasilan Pasal 21 (PPh 21) per bulan dari Alfred adalah sebagai berikut :

Penghasilan Bruto :

Gaji pokok sebulan

Tunjangan

Total Penghasilan Bruto

Pengurangan :

Biaya Jabatan (5\%)

Penghasilan Neto

Penghasilan Tidak Kena Pajak :

Wajib Pajak sendiri

Kawin - Istri (K)

168.750

Kawin - Anak $1(\mathrm{~K} / 1)$

168.750

Total Penghasilan Tidak Kena Pajak

Pajak Penghasilan 21 sebulan jika memiliki NPWP : 
Pajak Penghasilan 21 sebulan jika tanpa NPWP : Rp. 2.482.500 x 5\% x $120 \%$

4. Wajib Pajak Kawin dengan Tanggungan 2 Anak.

Alfred adalah seorang karyawan pada sebuah perusahaan swasta, yang menerima gaji per bulan sebesar Rp. 4.500.000, ditambah dengan tunjangan per bulan lainnya sebesar Rp. 600.000. Status perkawinan Alfred pada tanggal 1 Januari 2014 adalah kawin dengan memiliki 2 orang anak. Dalam hal ini, perhitungan Pajak Penghasilan Pasal 21 (PPh 21) per bulan dari Alfred adalah sebagai berikut :

Penghasilan Bruto :

Gaji pokok sebulan

4.500 .000

Tunjangan

Total Penghasilan Bruto

Pengurangan :

Biaya Jabatan (5\%)

Penghasilan Neto

$\frac{255.000}{4.845 .000}$

Penghasilan Tidak Kena Pajak :

Wajib Pajak sendiri

2.025 .000

Kawin - Istri (K)

168.750

Kawin - Anak $1(\mathrm{~K} / 1)$

168.750

Kawin - Anak $2(\mathrm{~K} / 2)$

168.750

Total Penghasilan Tidak Kena Pajak

Penghasilan Kena Pajak

Pajak Penghasilan 21 sebulan jika memiliki NPWP :

Rp. 2.313.750 x 5\%

115.688

\section{Pajak Penghasilan 21 sebulan jika tanpa NPWP :}

Rp. 2.313.750 x $5 \%$ x $120 \%$

138.825

5. Wajib Pajak Kawin dengan Tanggungan 3 Anak.

Alfred adalah seorang karyawan pada sebuah perusahaan swasta, yang menerima gaji per bulan sebesar Rp. 4.500.000, ditambah dengan tunjangan per bulan lainnya sebesar Rp. 600.000. Status perkawinan Alfred pada tanggal 1 Januari 2014 adalah kawin dengan memiliki 3 orang anak. Dalam hal ini, perhitungan Pajak Penghasilan Pasal 21 (PPh 21) per bulan dari Alfred adalah sebagai berikut :

Penghasilan Bruto :

Gaji pokok sebulan

Tunjangan

Total Penghasilan Bruto

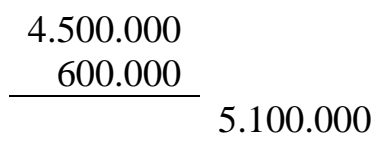

Pengurangan :

Biaya Jabatan $(5 \%)$

255.000

Penghasilan Neto

4.845 .000

Penghasilan Tidak Kena Pajak : 


\author{
Wajib Pajak sendiri \\ Kawin - Istri (K) \\ Kawin - Anak $1(\mathrm{~K} / 1)$ \\ Kawin - Anak $2(\mathrm{~K} / 2)$ \\ Kawin - Anak $3(\mathrm{~K} / 3)$ \\ Total Penghasilan Tidak Kena Pajak \\ Penghasilan Kena Pajak
}

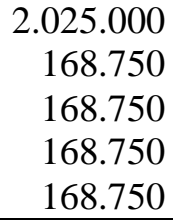

168.750

168.750

168.750

\section{Pajak Penghasilan 21 sebulan jika memiliki NPWP : Rp. 2.145.000 x 5\%}

107.250

\section{Pajak Penghasilan 21 sebulan jika tanpa NPWP : Rp. 2.145.000 x 5\% x 120\%}

\section{KESIMPULAN DAN SARAN}

\subsection{Kesimpulan}

Pajak penghasilan pasal 21 adalah pajak yang dikenakan atas penghasilan termasuk di dalamnya adalah penghasilan teratur. Dalam penghitungan Pajak Penghasilan pasal 21 perlu diperhatikan penyesuaian-penyesuaian atas Penghasilan Tidak Kena Pajak yang ditetapkan oleh pemerintah agar tidak terjadi pelaporan pajak lebih bayar. Selain itu, perlu diperhatikan bahwa fasilitas yang diberikan oleh pemerintah atas wajib pajak mengenai tanggungan dalam keluarga.

\subsection{Saran}

Penerapan atas aplikasi penghitungan Pajak Penghasilan Pasal 21 perlu memperhatikan target kelompok masyarakat yang menjadi objek pajak PPh 21, disebabkan karena tidak semua masyarakat yang memiliki penghasilan adalah objek pajak untuk Pajak Penghasilan Pasal 21.

\section{DAFTAR PUSTAKA}

Anggarsari, Susi Diah. 2010. Analisis Perlakuan Pajak Penghasilan Bagi Wajib Pajak Wanita Kawin. Jurnal Ilmu Administrasi dan Organisasi, Vol.17, No.2.

Dewanata, Pandu, dkk. 2013. Analisis Perhitungan dan Pelaporan Pajak Penghasilan Pasal 21 pada PT. Gatra Kaltim Jaya Kota Balikpapan. Jurnal Riset Akuntansi Going Concern, Vol. 8 No. 4, Desember.

Ernawati, Sri \& Wijaya, Mellyana. 2011. Pengaruh Pemahaman Akuntansi Pajak Terhadap Kepatuhan Wajib Pajak Badan Usaha di bidang Perdagangan di Kantor Pelayanan Pajak Pratama Banjarmasin. Jurnal Spred - April 2011, Volume 1 Nomor 1.

Lumbantoruan, Amber. 2001. Faktor- Faktor yang mempengaruhi Minat Wajib Pajak untuk Menyelenggarakan Pembukuan setelah Pelaksanaan Undang-undang Pajak Penghasilan. Jurnal Ilmiah Akuntansi, Vol. 1 No.1.

Mardiasmo. 2011. Perpajakan. Penerbit Andi Jogjakarta.

Republik Indonesia. 2008. Undang-Undang Nomor 36 tentang Perubahan Keempat atas Undang-Undang Nomor 7 Tahun 1983 tentang Pajak Penghasilan.

Republik Indonesia, Kementerian Keuangan - Direktorat Penyuluhan Pelayanan dan Hubungan Masyarakat. 2011. Susunan dalam Satu Naskah Undang-Undang Perpajakan.

Republik Indonesia, Direktur Jenderal Pajak. 2012. Pedoman Teknis Tata Cara Pemotongan, Penyetoran dan Pelaporan Pajak Penghasilan Pasal 21 dan/atau Pajak Penghasilan 
Pasal 26 sehubungan dengan Pekerjaan, Jasa, dan Kegiatan Orang Pribadi, PER 31/PJ/2012.

Republik Indonesia, Menteri Keuangan. 2012. Penyesuaian Besarnya Penghasilan Tidak Kena Pajak, 162/PMK.011/2012.

Setiyaji, Gunawan \& Amir, Hidayat. 2005. Evaluasi Kinerja Sistem Perpajakan Indonesia. Jurnal Ekonomi, Universitas Indonusa Esa Unggul.

Suprajadi, Lusy. 1999. PPh pasal 21 ditunjang atau ditanggung ? Bina Ekonomi, Agustus. 